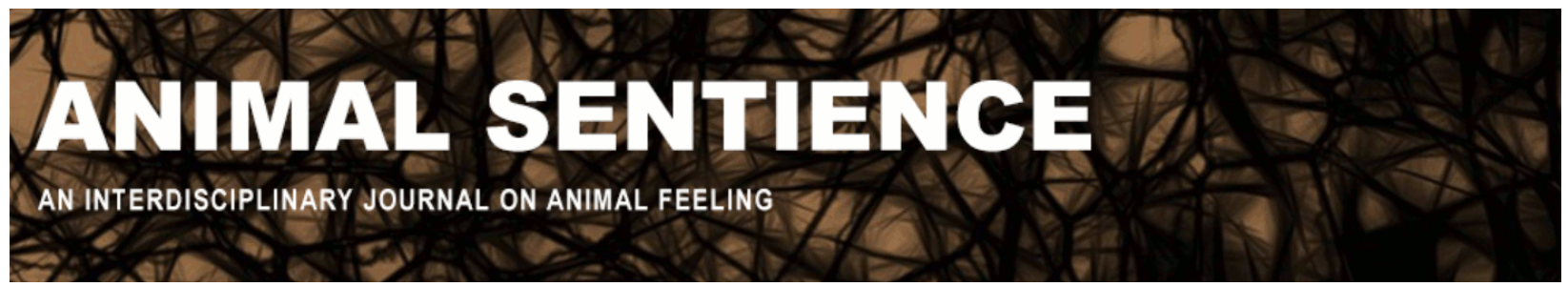

Brooks Pribac, Teya (2017) Complicated grief. Animal Sentience 20(9)

DOI: $10.51291 / 2377-7478.1294$

Date of submission: 2018-01-09

Date of acceptance: 2018-01-16

(c) (i)

This article has appeared in the journal Animal

Sentience, a peer-reviewed journal on animal

cognition and feeling. It has been made open access,

free for all, by WellBeing International and deposited

in the WBI Studies Repository. For more information,

please contact

wbisr-info@wellbeingintl.org.

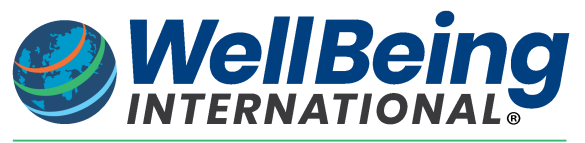

SOLUTIONS FOR PEOPLE, ANIMALS AND ENVIRONMENT 


\title{
Complicated grief
}

Commentary on Peña-Guzmán on Animal Suicide

\author{
Teya Brooks Pribac \\ Department of Studies in Religion \\ University of Sydney
}

\begin{abstract}
My commentary discusses complicated grief and the ensuing sense of helplessness that
\end{abstract} may lead to suicide. I close with a story about a pygmy pig.

Teya Brooks Pribac works in animal advocacy/care between Australia and Europe. She is currently completing a PhD in animal grief. She lives in the Australian Blue Mountains with sheep and other animals. http://bit.ly/BrooksPribac

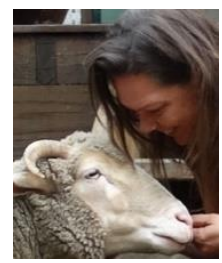

Peña-Guzmán (2017) argues convincingly for the possibility of suicide in nonhuman animals and its ethical implications. His article is at the same time a welcome reminder that "we can do justice to the miracle of the [elephant] trunk without pretending that nobody else has a nose" (Midgley 1979/2002, p. 198). Rather than being a choice of free will (an idea that Peña-Guzmán himself shows to be inconsistent), suicide occurs when individuals feel there is no other choice, even though they may think of various alternatives. As Peña-Guzmán points out, the process tends to begin before intent to die forms (if the latter occurs at all).

The source of some of these negative feelings and related implicit memories may be inaccessible to conscious reflection. This has led human psychotherapy to put greater emphasis on developmental contexts and bodily-focused approaches (e.g., Schore 2012, Payne et al. 2015). Other animals' minds are also shaped by developmental conditions and equally vulnerable to stressors (e.g., Bradshaw 2009). The dogs starving themselves to death after their guardians' passing (Preti 2007) may have been suffering from "complicated grief."

Various factors may contribute to the emergence of complicated grief, including attachment styles. Individuals with an insecure/anxious attachment style are at higher risk of developing the condition because they are "wired" for clinging; the brain becomes organized in such a way that it chronically searches for cues indicating the availability of the attachment figure, quickly detecting cues of unavailability (Fraley and Shaver 2016). With such a brain organization, when loss occurs, the individual may not be capable of overriding the insecurity and the propensity/compulsion for searching. This may then lead to prolonged grief and the inability to adjust to the loss - a condition also sustained by simultaneous pain- and reward-related neural activity (the latter is absent in non-complicated grief). This produces a craving for the lost object (O'Connor et al. 2008). If this obsessive cycle is not broken, it can have a severe impact on the individual's long-term psychological and physiological well-being. Captive animals (including companion animals) are usually not afforded a normative species-specific upbringing that fosters 
security of attachment. They may thus be more vulnerable to unfavorable outcomes following loss.

Liza, a pot-belly sow brought to a "farm" animal sanctuary from a non-commercial farm, had had a litter before; several piglets were born physically deformed and dead. One deformed piglet was born alive but died soon after; three were born healthy. Her next significant experience was a second pregnancy, most likely perpetrated by her own son. This pregnancy was not noticed until, now at the sanctuary, Liza had suddenly fallen ill, refusing food and water.

Other than the pregnancy itself, the veterinary examination yielded no diagnosis. Syringefeeding and watering was difficult, as she would clench her teeth and spit out anything that managed to penetrate the enamel barrier. She had been in this condition for two weeks when I agreed to help look after her over a weekend while the personnel were attending to other tasks.

I lay down beside her, our bodies lightly touching, calm, quiet, breathing normally, and remained there all day. Two hours later, she reluctantly opened her mouth and took some food. The following morning, she went into labor, two to three weeks premature. It lasted thirty-six hours. Chemical induction administered by the visiting veterinarian did little to accelerate the process; manual extraction was ruled out given her size, and she was too weak for a surgical procedure. All eleven fetuses were delivered dead. Liza herself was exhausted but alive, and still is.

I don't know whether Liza was suicidal following her cumulative life experiences, as some eye-witnesses had speculated, or whether some undetected medical factor caused her pitiable condition. Equally mysterious to me is the inability of most humans to see how profoundly perverse it is to enslave other animal females and routinely impregnate them so the humans can eat their infants or drink their infants' milk.

\section{References}

Bradshaw, G.A. (2009). Elephants on The Edge: What Animals Teach Us About Humanity. New Haven: Yale University Press.

Fraley, C.R., \& Shaver, P.R. (2016). Attachment, loss, and grief: Bowlby's views, new developments, and current controversies. Handbook of Attachment: Theory, Research, and Clinical Applications ( $3^{\text {rd }}$ edition), edited by J. Cassidy \& P.R. Shaver. New York: The Guilford Press, 40-62.

Midgley, M. (2002 [1979]). Beast and Man: The Roots of Human Nature. London: Routledge. O'Connor, M-F., Wellisch, D.K., Stanton, A.L., Eisenberger, N.I., Irwin, M.R., \& Lieberman, M.D. (2008). Craving Love? Enduring grief activates brain's reward center. Neuroimage, 42(2), 969-972.

Payne, P., Levine, P.A., \& Crane-Godreau, M.A. (2015). Somatic experiencing: Using interoception and proprioception as core elements of trauma recovery. Frontiers in Psychology, 6(93), 1-18.

Peña-Guzmán, D.M. (2017). Can nonhuman animals commit suicide? Animal Sentience 20(1). Preti, A. (2007). Suicide among animals: A review of evidence. Psychological Reports, 101, 831848.

Schore, A.N. (2012). The Science of the Art of Psychotherapy. New York: W.W. Norton \& Company. 